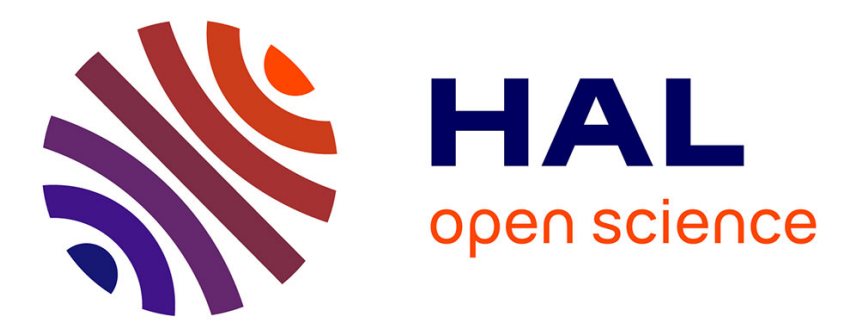

\title{
Arrival date and territorial behavior are associated with corticosterone metabolite levels in a migratory bird
}

Elisa Lobato, Juan Moreno, Santiago Merino, Judith Morales, Gustavo

Tomás, Javier Martínez, Rodrigo A. Vásquez, Alexandra Kuchar, Erich Möstl, José Luis Osorno

\section{To cite this version:}

Elisa Lobato, Juan Moreno, Santiago Merino, Judith Morales, Gustavo Tomás, et al.. Arrival date and territorial behavior are associated with corticosterone metabolite levels in a migratory bird. Journal für Ornithologie = Journal of Ornithology, 2010, 151 (3), pp.587-597. 10.1007/s10336-009-0488-x . hal-00555321

\section{HAL Id: hal-00555321 \\ https://hal.science/hal-00555321}

Submitted on 13 Jan 2011

HAL is a multi-disciplinary open access archive for the deposit and dissemination of scientific research documents, whether they are published or not. The documents may come from teaching and research institutions in France or abroad, or from public or private research centers.
L'archive ouverte pluridisciplinaire HAL, est destinée au dépôt et à la diffusion de documents scientifiques de niveau recherche, publiés ou non, émanant des établissements d'enseignement et de recherche français ou étrangers, des laboratoires publics ou privés. 


\title{
Arrival date and territorial behavior are associated with corticosterone metabolite levels in a migratory bird
}

\author{
Elisa Lobato $\cdot$ Juan Moreno $\cdot$ Santiago Merino $\cdot$ Judith Morales $\cdot$ \\ Gustavo Tomás · Javier Martínez $\cdot$ Rodrigo A. Vásquez • Alexandra Kuchar • \\ Erich Möstl · José Luis Osorno
}

Received: 1 May 2009/Revised: 7 October 2009/Accepted: 21 December 2009/Published online: 13 January 2010

(C) Dt. Ornithologen-Gesellschaft e.V. 2010

\begin{abstract}
Glucocorticoids promote the mobilization of energy stores and they may facilitate the expression of energetically expensive functions. Early arrival on the breeding grounds in migratory species and territorial competition are energetically demanding activities that may be supported by elevated baseline glucocorticoid levels. Here, we evaluated the associations between the baseline levels of excreted corticosterone (CORT) metabolites of male Pied Flycatchers (Ficedula hypoleuca) just after arriving on their breeding area and timing of arrival, considering ornamental traits indicative of social status, like forehead patch size and black plumage coloration, as well as heat shock protein levels (HSP60). We observed a positive association of CORT metabolites with HSP60 levels, which are synthesized under several environmental challenges affecting cell
\end{abstract}

J. L. Osorno: Deceased.

Communicated by C. G. Guglielmo.

E. Lobato $(\varangle) \cdot$ J. Moreno · S. Merino · J. Morales · G. Tomás Departamento de Ecología Evolutiva, Museo Nacional de Ciencias Naturales, J. Gutiérrez Abascal 2, 28006 Madrid, Spain e-mail: elobato@mncn.csic.es

\section{J. Martínez}

Departamento de Microbiología y Parasitología,

Facultad de Farmacia, Universidad de Alcalá,

Alcalá de Henares, 28871 Madrid, Spain

R. A. Vásquez

Departamento de Ciencias Ecológicas, Facultad de Ciencias, Instituto de Ecología y Biodiversidad, Universidad de Chile, Casilla 653, Santiago, Chile

\section{A. Kuchar · E. Möstl}

Department of Biomedical Sciences, Institute of Biochemistry, University of Veterinary Medicine, Veterinärplatz 1,

1210 Vienna, Austria homeostasis. Our data showed a negative association between arrival date and CORT metabolite levels, possibly as a result of the higher energetic demands imposed by the hard environmental conditions experienced at the time of an early arrival after migration. We observed a negative relationship of forehead patch dimensions and CORT metabolite levels, suggesting that dominance is associated with low baseline CORT metabolites. Also, males that expressed a higher degree of territorial behaviour when exposed to a playback song of a conspecific at their nest-box showed higher CORT metabolites upon arrival than males that expressed a lower degree of territorial behavior. This may indicate that elevated baseline CORT metabolite levels may facilitate an intense territorial competition in males. Thus, male-male competition may be a factor affecting observed baseline glucocorticoid levels in migratory birds.

Keywords Arrival date $\cdot$ Glucocorticoid $\cdot$ Heat shock proteins $\cdot$ Forehead patch $\cdot$ Territorial behavior

Present Address:

G. Tomás

Departamento de Ecología Evolutiva, Instituto de Ecología,

Universidad Nacional Autónoma de México, AP 70-275,

04510 Mexico, D.F., México

Present Address:

E. Lobato

Centre d'Ecologie Fonctionelle et Evolutive,

CNRS UMR 5175, 34293 Montpellier, France

Present Address:

J. Morales

Departamento de Ecoloxía e Bioloxía Animal,

Facultade de Bioloxía, Universidade de Vigo,

36310 Vigo, Spain 


\section{Introduction}

The expression of sexually selected traits may be limited by ecological and physiological constraints (Andersson 1994). In order to unravel the physiological constraints involved in the evolution of sexually selected traits, the proximate mechanisms mediating the expression of these traits need to be understood. The endocrine system provides a mechanism by which the regulation of physiological and behavioral changes may take place (Becker and Breedlove 2002). In particular, glucocorticoids are important mediators of allostasis, as they support readjustment of behavior and physiology (McEwen and Wingfield 2003). At low baseline levels, glucocorticoids support daily life processes and, at elevated baseline levels, these hormones support predictable life history stages associated with high allostatic load or energy demand (Landys et al. 2006). The stress-related levels of glucocorticoids are expected under life-threatening perturbations associated with allostatic overload or energy demands that exceed the requirement of the current life history stage (Landys et al. 2006). Because of the role of CORT in energy mobilization and distribution and its involvement in cardiovascular, immune, or nervous diseases when secreted at high levels over long periods (Sapolsky et al. 2000; Sapolsky 2000), it is possible that this hormone may also be involved in the expression of costly behaviors and characters and may provide a mechanistic link between the expression of these traits and diverse selective processes (Husak and Moore 2008). In fact, glucocorticoids have been suggested to be under the direct or indirect influence of sexual selection (reviewed in Husak and Moore 2008).

In migratory species, the pattern of arrival to the breeding grounds after migration and the defense of territories may be under the influence of sexual selection. The study of the variation of glucocorticoid levels in association with these patterns could provide important information about the involvement of these hormones in the expression of sexually selected traits. Migration constitutes a predictable life-history stage that imposes high energetic demands on birds and may be associated with elevated baseline levels of glucocorticoids (Landys-Ciannelli et al. 2002). In several species, migration is associated with elevated levels of corticosterone (CORT), the predominant glucocorticoid in birds (Holberton et al. 1996; Romero et al. 1997; Holberton 1999; Piersma et al. 2000), and this association could be indicative of a role of this hormone in promoting energy acquisition at this stage. Moreover, CORT is suggested to play a regulatory role specifically associated with migratory flight (Landys-Ciannelli et al. 2002; Landys et al. 2004). In addition, hard environmental conditions experienced during migration could elicit high energy requirements. Also, the pattern of arrival on the breeding sites after migration may be related to differences in the exposure to hard environmental conditions. Particularly, early-arriving individuals may be subjected to harsher weather conditions or food scarcity (Møller 1994; Brown and Brown 2000; Newton 2007). At the same time, early arrival may be advantageous for acquiring high quality territories and may increase the probability of mating (e.g., Potti and Montalvo 1991a; Kokko 1999; Smith and Moore 2005). Therefore, an early arrival after migration is presumably a character positively influenced by sexual selection that entails costs derived from severe environmental conditions (Darwin 1871; Fisher 1930; Møller 1994; Kokko 1999). The study of the levels of CORT metabolites just after migration in relation to arrival date may give us insight into the physiological mechanisms that support the elevated energy demand associated with early arrival.

Territorial defense is also a costly activity closely related to sexual selection (Andersson 1994). The defense of territories may be carried out by means of visual and auditory signals such as flight displays, songs, or calls, and may even involve chasing or attacking. Territorial defense may be costly due to elevated energy expenditure (i.e., Davies 1980) and to other costs associated with this behavior such as less time available for foraging and higher predation or injury risk (Krebs 1980). Recent studies have suggested that the secretion of CORT may facilitate energy mobilization during continuous aggressive or defensive behaviors (Moore and Jessop 2003; Goymann and Wingfield 2004; Berger et al. 2005). It has also been reported that territorial aggression in birds causes a rapid increase in CORT levels, suggesting that this hormone may play a specific role in the regulation of territorial behavior (Landys et al. 2007). In fact, studies on rodents indicate that glucocorticoids may act directly on the facilitation of aggressive behaviors (Hayden-Hixson and Ferris 1991; Haller et al. 1997).

Other secondary sexually selected traits such as plumage characteristics may be condition-dependent and costly to produce or maintain (e.g., Gustafsson et al. 1995). One of the physiological costs that the expression of secondary sexual characters may impose is that derived from the impairment of the functioning of the immune system (Saino and Møller 1995; Kilpimaa et al. 2004). It has been suggested that this cost may arise due to the immunosuppressive effects of sex steroids that facilitate the expression of secondary sexual traits (Folstad and Karter 1992) and also as a result of the allocation of resources to different costly traits (Råberg et al. 1998). It is also reported that dominance may explain variation in glucocorticoid levels, as some studies have found that subordinates show high baseline glucocorticoid levels (i.e., Schwabl et al. 1988; Belthoff and Dufty 1994; see also Creel 2001 for noncooperative breeders), while other studies did not find an 
association between social rank and baseline hormone levels (i.e., Holberton et al. 1989; Pravosudov et al. 2003). In general, as reviewed by Goymann and Wingfield (2004), social conflicts may increase the energetic demands which is reflected in increased concentrations of glucocorticoids, and it is the relative allostatic load of social status that may determine the glucocorticoid levels of dominants and subordinate individuals. As social dominance may be related to early arrival and territorial behavior, it is necessary to control for social dominance in any analysis testing to see if early arrival and territorial aggression are associated with elevated CORT levels.

The elevated secretion of CORT in high demanding situations may be related to other physiological parameters that support processes associated with elevated energy requirements. For example, the cellular levels of heat shock proteins (HSPs) are good indicators of the exposition to different stressors in several species (Merino et al. 1998, 2002; Feder and Hofmann 1999; Martínez et al. 2001; Moreno et al. 2002; Tomás et al. 2005; for a review, see Sørensen et al. 2003). HSPs are molecular chaperones that protect proteins from damage by means of their role in the maintenance of the functional conformation of protein structures and degradation of damaged proteins (Schlesinger 1990; Sørensen et al. 2003). They are constitutively expressed to assist daily metabolic processes involving synthesis and degradation of proteins (Feige and Polla 1994). The inducible transcription of heat shock genes is associated with the exposure to situations that destabilize cell homeostasis and produce alterations in protein folding (Morimoto 1998). The increase in HSPs after an environmental challenge may last longer than other physiological responses, such as changes in glucocorticoid levels (Herring and Gawlik 2007). Moreover, HSP measure is independent of handling stress (Washburn et al. 2002) and appropriate to measure long-term stress (Herring and Gawlik 2007). Similarly, in order to avoid problems induced by a rapid increase of CORT after handling of birds (Romero and Romero 2002), we used non-invasive measures of CORT metabolites in excreta of male Pied Flycatchers (Ficedula hypoleuca) that provide a hormonal measure independent of capture stress. Steroid metabolites concentrations in excreta constitute an integrated parameter of steroid levels over a long period of time (Goymann 2005) and may provide an accurate measure of long-term glucocorticoid levels (see Millspaugh and Washburn 2004). Therefore, the study of the association between HSPs and CORT metabolite levels may provide information about the general physiological state associated with the expression of high levels of glucocorticoids in a given situation.

In the present study, we tested the hypotheses that early arrival to the breeding grounds and territorial male-male competition are associated with elevated baseline levels of CORT metabolites in a tropical migrant, the Pied Flycatcher. We analyzed the association of the levels of CORT metabolites of male Pied Flycatchers just after arriving on the breeding area with timing of arrival. This test is controlled for the associations of social dominance with CORT metabolite levels by introducing two plumage traits that have been linked to male dominance in Pied Flycatchers, the white forehead patch size (Pärt and Qvarnström 1997) and the amount of black plumage coloration (Järvi et al. 1987). We also considered the HSP levels in the analyses as a measure of physiological response that may assist processes of protein synthesis and degradation during situations of elevated energy requirement. We also evaluated the associations of the levels of CORT metabolites of male Pied Flycatchers with two measures of territorial behavior, approaching and singing to an intruder. We considered the size of the forehead patch in the statistical analyses, as males with experimentally enlarged patches have been shown to express more intense territorial behavior (Osorno et. al. 2006).

\section{Methods}

\section{Capture and handling}

The study was conducted in 2003 in a deciduous forest of Pyrennean oak Quercus pyrenaica at 1,200 m a.s.l. in the vicinity of La Granja, Segovia province, central Spain $\left(40^{\circ} 53^{\prime} \mathrm{N}, 4^{\circ} 01^{\prime} \mathrm{W}\right.$.). The Pied Flycatcher is a small $(12-$ $13 \mathrm{~g}$ ) hole-nesting migratory passerine of European woodlands (Lundberg and Alatalo 1992). The population of Pied Flycatchers in the study area has been monitored since 1991 (see Sanz et al. 2003). From mid-April, the study area was exhaustively searched for newly arrived males. The Pied Flycatcher is a tropical migrant that has a short time window available for reproduction. Males sing immediately upon arrival on the breeding grounds and get involved in territorial competition, in order to achieve and establish their territory, and start breeding as soon as possible (Lundberg and Alatalo 1992; own observations). The song of Pied Flycatchers is unmistakable and their black and white plumage is very conspicuous. This makes their detection easy to an experienced observer, particularly at the beginning of the reproductive season, when the leaves of the oaks in the forest have not yet sprouted and the visibility is very good. Also, given that the territory defended by these males is restricted to the nestbox (Lundberg and Alatalo 1992), and the fact that they sing close to these boxes, makes their detection even easier. In our study, six expert ornithologists combed the whole study area before any male had arrived in a daily, systematic and 
exhaustive search for newly arrived Pied Flycatchers. We thus assumed that the first day a male was observed singing was the day of his arrival. Pied Flycatcher males were captured with nestbox traps on their first day of observation in the study area. They were identified or ringed in cases when they were not previously ringed, weighed with a Pesola spring balance (accuracy of $0.05 \mathrm{~g}$ ), and their tarsus length was measured with a digital calliper to the nearest $0.01 \mathrm{~mm}$ (apparatus precision). As a measure of body condition, we used the ratio body mass/cube of tarsus length. We measured the white forehead patch of rectangular shape that Ficedula males exhibit (Osorno et al. 2006). The patch size was estimated by multiplying the width and height as measured to the nearest $0.01 \mathrm{~mm}$ with a digital calliper. The percentage of black feathers in the head and mantle was scored as 'blackness', which is the exact inverse of the brownness score used by Potti and Montalvo (1991b). This score is highly correlated (Potti and Montalvo 1991b) with Drost's (1936) scale from I (darkest) to VII (lightest). Blackness scores were converted to 10-point intervals, with values ranging from 0 (0-10\%) to 9 (90-100\%). Male age was determined according to plumage characteristics following Svensson (1984) or by previous ringing. All males were individually marked with color rings to allow identification in behavioral observations of territorial response on the following days (see below). At the time of capture, males were subjected to a forehead patch manipulation with the aid of black or white permanent paint markers in the context of a previously published study on the role of forehead patch size on differential maternal allocation of resources to eggs (Osorno et al. 2006). Males were randomly assigned to one of three experimental groups: enlarged-patch, control, and reducedpatch. The modified patch size was measured in all cases. This modified patch size has only been considered in analyses explaining territorial response (see below), as these behavioral measures were taken after the treatment was performed, and they could be affected by the manipulation. The original patch size and not the modified patch size was considered in analyses explaining the variation in CORT metabolites as all explanatory variables considered had been taken before the treatment was performed.

In order to measure the concentration of excreted CORT metabolites, fresh excreta of male Pied Flycatchers were collected in $1.5-\mathrm{ml}$ plastic vials, stored in cool bags with cold-blocks (not exceeding $15^{\circ} \mathrm{C}$ ) and frozen at $-20^{\circ} \mathrm{C}$ (1-5 h later) until laboratory analyses. Droppings were obtained by spontaneous defecation during the process of ringing. In order to increase sample size, when they did not defecate during the ringing process, they were introduced for some minutes into a dark wooden box to collect faeces from aluminium foil placed on the bottom of the box. To measure the levels of HSPs, a blood sample of approximately $80 \mu \mathrm{l}$ was obtained by brachial venipuncture. Blood samples were centrifuged $(2,000 \mathrm{~g}, 5 \mathrm{~min})$ in a field centrifuge (MiniCentrifuge, Cat. No 1201-220V; Labnet, Woodbridge, NJ, USA).The cellular and plasma fractions were separated and cold-stored until frozen at the end of the day not exceeding $8 \mathrm{~h}$ from collection which allows a reliable measure of stress proteins as shown by Tomás et al. (2004). The blood cellular fraction was used for further analyses.

\section{Territorial response observations}

A few days after capture $(5.5 \pm 0.8$, mean $\pm \mathrm{SE}, n=36)$ and before initiation of nest building in their nestbox by females, the territorial response of each male was measured by observations during $10 \mathrm{~min}$. A digital commercial recorder (Mundi Sound PQ10; Great Britain) playing Pied Flycatcher song was placed on the ground below the nestbox defended by a certain color-banded male (for details of territorial response observations, see Osorno et al. 2006). We used song from a single bird in all cases, so the responses to it have to be interpreted cautiously (Kroodsma et al. 2001). The recorder played a sequence of several vocalizations of Pied Flycatcher song of one individual from an unspecified Pied Flycatcher population. It is highly unlikely that the song recorded would be individually recognizable. Song rate was not atypical (about 40 strophes per $5 \mathrm{~min}$ ) and falls within the natural range of an adult Pied Flycatcher male (e.g., average of 37.9 strophes per $5 \mathrm{~min}$; Gottlander 1987). We assume that responses to this specific song reflect responses of males to circumstances when territorial intrusions may be associated to CORT metabolite levels, an assumption which may be unwarranted. A single song bout was used only once on each subject and gave rise to a unique data point. It is not likely that neighbors of subjects could hear the recording as the digital recorder was played at a volume that could presumably only be heard at a short distance from the subject. The volume of the loudspeaker was adjusted so that it could only be heard at a short distance from the nestbox of the subject male (at $50 \mathrm{~m}$, the average distance between nestboxes in the study area, the playback song could not be heard by us). Each male's response was registered by an observer (always the same) hidden at a distance of at least $15 \mathrm{~m}$. The approximation (whether a male approached to the playback recorder until almost touching it or not) and singing (whether males sang or not) behavior was registered during the 10-min playback observations. A second observation of territorial response was measured $13.2( \pm 1.0, n=34)$ days after capture (see Osorno et al. 2006), but for the study of the association of CORT metabolite levels and territorial response we only used the first observation, as this avoids problems of habituation, 
and it was temporally closer to the CORT metabolites measure.

\section{Measurement of excreted CORT metabolites}

In small birds, the study of droppings as a source of information of hormonal status is particularly useful due to the small volume of blood that can be obtained and the analytical disadvantages of small volumes of plasma. Steroid metabolites concentrations in excreta represent an integral measure of hormone metabolites (Goymann 2005). Radiometabolism studies have determined that the length of the integral may range a few hours in birds (reviewed in Palme et al. 2005). Thus, in our study, the integrated measure of CORT metabolites from samples obtained of birds on the day of their arrival refers to the CORT metabolite levels at the last stage of migration and the onset of territory acquisition. Excreta were homogenized, and steroids were extracted as described in Lobato et al. (2008). The concentration (ng/g) of excreted immunoreactive CORT metabolites was measured by means of the cortisone enzyme immunoassay described by Rettenbacher et al. (2004), validated for Pied Flycatchers by Lobato et al. (2008). Enzyme immunoassays were performed on antirabbit-IgG-coated microtitre plates using the double antibody technique and biotinylated steroids as labels. Details of the procedure of the assay are described in Möstl et al. (2002).

\section{Determination of heat shock proteins}

The levels of HSP60 were determined from the blood cellular fraction by means of western blotting following the methodology described in Tomás et al. (2004). Protein bands were quantified using image analysis software for Windows (Scion Corporation) and immunoreactivities (arbitrary units) were obtained using the formula: Immunoreactivity $=$ area $\times$ mean intensity of the band.

\section{Statistics}

We first evaluated the independent variables that significantly predicted the levels of CORT metabolites of male Pied Flycatchers just after arrival from migration. The variables considered in the analyses were: arrival date ( $1=1$ April), body condition, HSP60 level, forehead patch size, plumage blackness, and male age. All these variables were introduced simultaneously as independent variables, and corticosterone metabolites as dependent variable, in a GLM (generalized linear models) analysis, using STATISTICA software. No interaction terms were considered. We systematically removed the variable with the lowest $F$ value and ran the model again until we reached a model with all covariates significantly associated with CORT metabolite levels at $P$ value $<0.05$.

We secondly analyzed if CORT metabolite levels predicted territorial behavior measured $5.5 \pm 0.8$ days after the sampling of droppings. We included in the analyses the arrival date, the original patch size, the modified forehead patch, and the levels of CORT metabolites as potential explanatory variables in GLM models with binomial distribution, with singing behavior (singing or not) and approaching behavior (approaching to playback recorder or not) as dependent variables in respective analyses. We systematically removed the covariates with lower associated Wald statistic until all covariates were significantly associated $(P$ value $<0.05)$ with the respective dependent variable.

\section{Results}

The final model explaining the variance in the concentration of excreted CORT metabolites after arriving from migration included arrival date, male HPS60 level, and the original forehead patch size as significant explanatory variables ( $n=18$, HSP60 level: $F_{1,14}=6.53, P=0.023, \beta=0.54$; arrival date: $F_{1,14}=5.48, P=0.035, \beta=-0.51$; forehead patch: $\left.F_{1,14}=5.09, P=0.041, \beta=-0.46\right)$. The adjusted $r^{2}$ of the model was 0.34 . The residuals of the model were normally distributed. The HSP60 level was positively associated with the level of excreted CORT metabolites (Fig. 1a). Early-arriving individuals showed higher concentrations of excreted CORT metabolites (Fig. 1b). Larger forehead patches were associated with lower concentrations of CORT metabolites (Fig. 1c).

The only variable that significantly explained singing behavior was CORT metabolite levels (Wald $=4.77$, $P=0.029$ ). Males that sang during the $10-\mathrm{min}$ observation period when playback was played showed higher levels of CORT metabolites at the moment of arrival from migration than males that did not sing during this period (Fig. 2a). Similarly, the only variable that significantly predicted approaching behavior was CORT metabolite levels (Wald $=4.55, P=0.033$ ). Males that approached the playback recorder during the playback showed higher levels of CORT metabolites than males that did not approach the recorder (Fig. 2b).

\section{Discussion}

Our data show that elevated CORT metabolite concentrations are positively associated with heat shock protein levels (HSP60) in Pied Flycatcher males just after arriving on their breeding area. Heat shock and glucocorticoid 

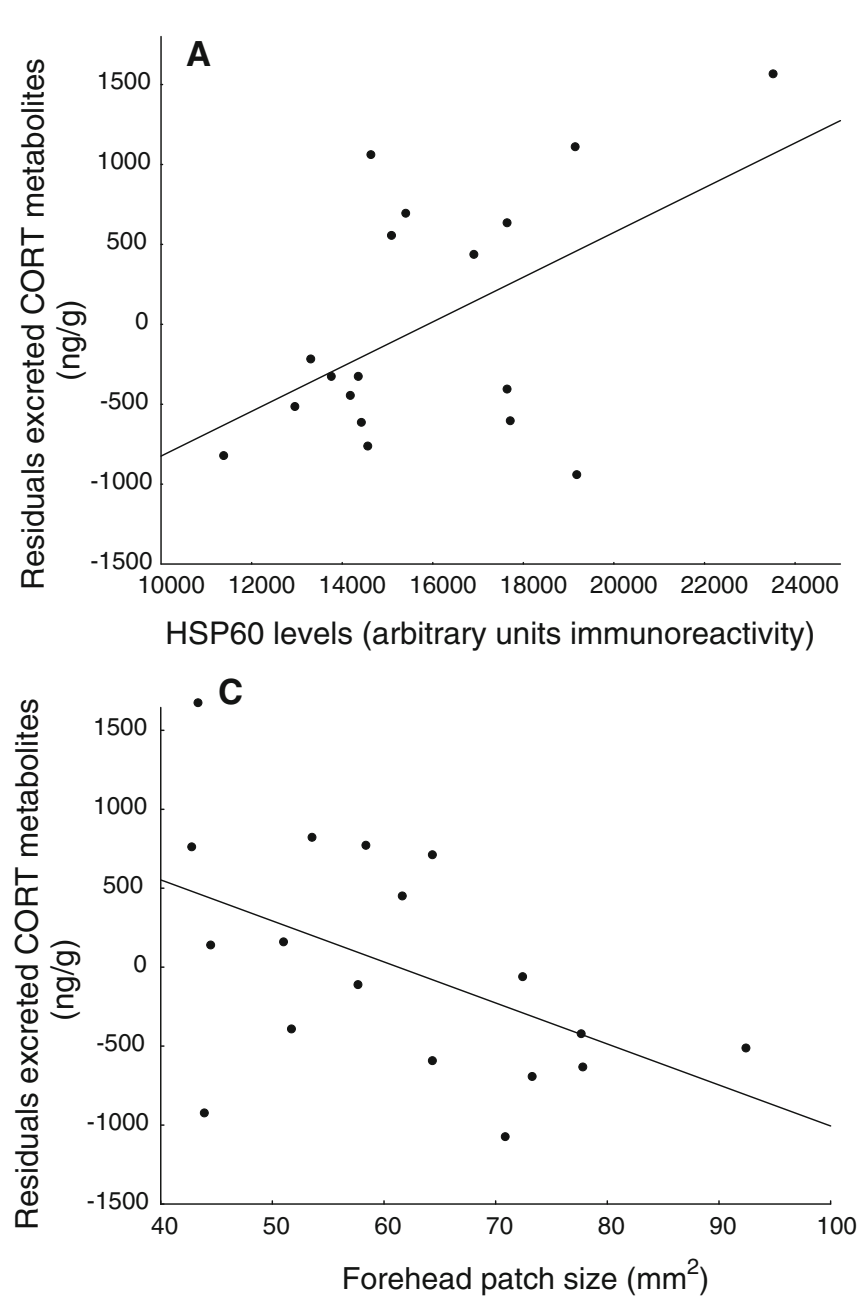

Fig. 1 a Association between HSP60 levels and the residuals of the regression of CORT metabolites on arrival date and forehead patch size. b Association between arrival date and the residuals of the

responses may be elicited under different environmental challenges, although the type or level of stimulus needed to induce each response may differ (Herring and Gawlik 2007). Also, these compounds may be synthesized to support daily metabolic processes and predictable lifehistory stages associated with high energy demand (i.e., Feige and Polla 1994; Landys et al. 2006). The positive association between CORT metabolites and HSP60 levels found in our study may arise because migration itself or the differential conditions experienced during migratory flight trigger both physiological responses that therefore appeared correlated just when males arrived on the breeding grounds. It has been suggested that elevated glucocorticoid levels may regulate the synthesis of some HSPs (HSP27: Barr and Dokas 1999; and HSP72: Fleshner et al. 2004). Also, it is known that high demanding activities such as physical exercise up-regulate proteins involved in energy metabolism and also specific proteins

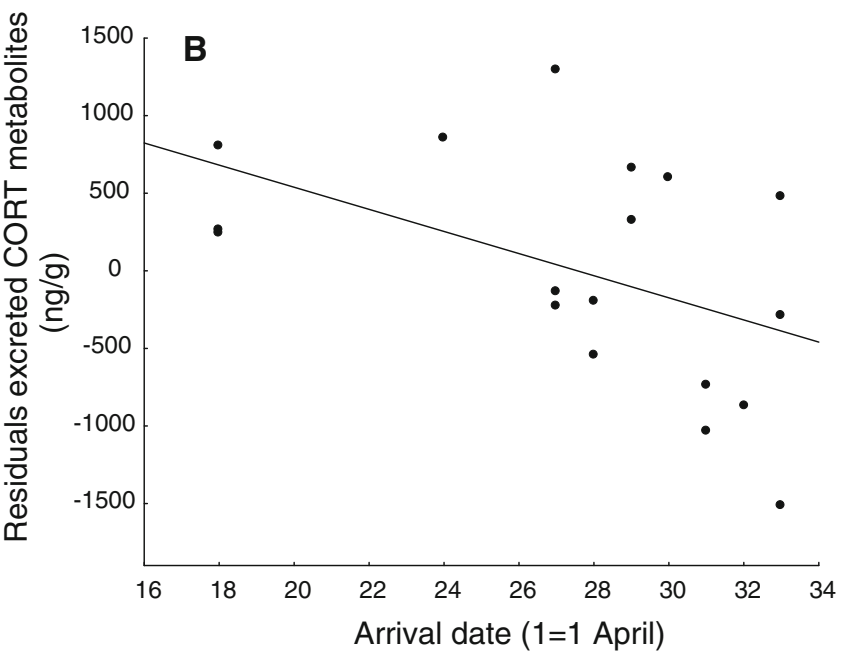

regression of CORT metabolites on forehead patch size and HSP60 levels. c Association between forehead patch size and the residuals of the regression of CORT metabolites on arrival date and HSP60 levels

such as molecular chaperones, particularly HSP60 (Ding et al. 2006; Thambirajah et al. 2008). This HSP may provide cellular protection during changes in protein metabolism and assist protein formation and degradation in anabolic and catabolic processes (Schäfler et al. 2002). In an avian model, adrenocorticotropic (ACTH) hormone administration increased corticosterone secretion and also other parameters such as haematocrit or the blood concentration of haemoglobin (Olanrewaju et al. 2006). This suggests that birds increased erythropoiesis to satisfy the need for $\mathrm{O}_{2}$ to support energy production after ACTH infusion (Olanrewaju et al. 2006). Considering that HSP60 was detected in the cellular fraction of blood in our study, our HSP measure indicates, for the most part, the level of these proteins in erythrocytes. Therefore, the positive association of CORT and HSP found here may reflect the elevated need of molecular chaperones in processes involving elevated haemoglobin synthesis during increased 

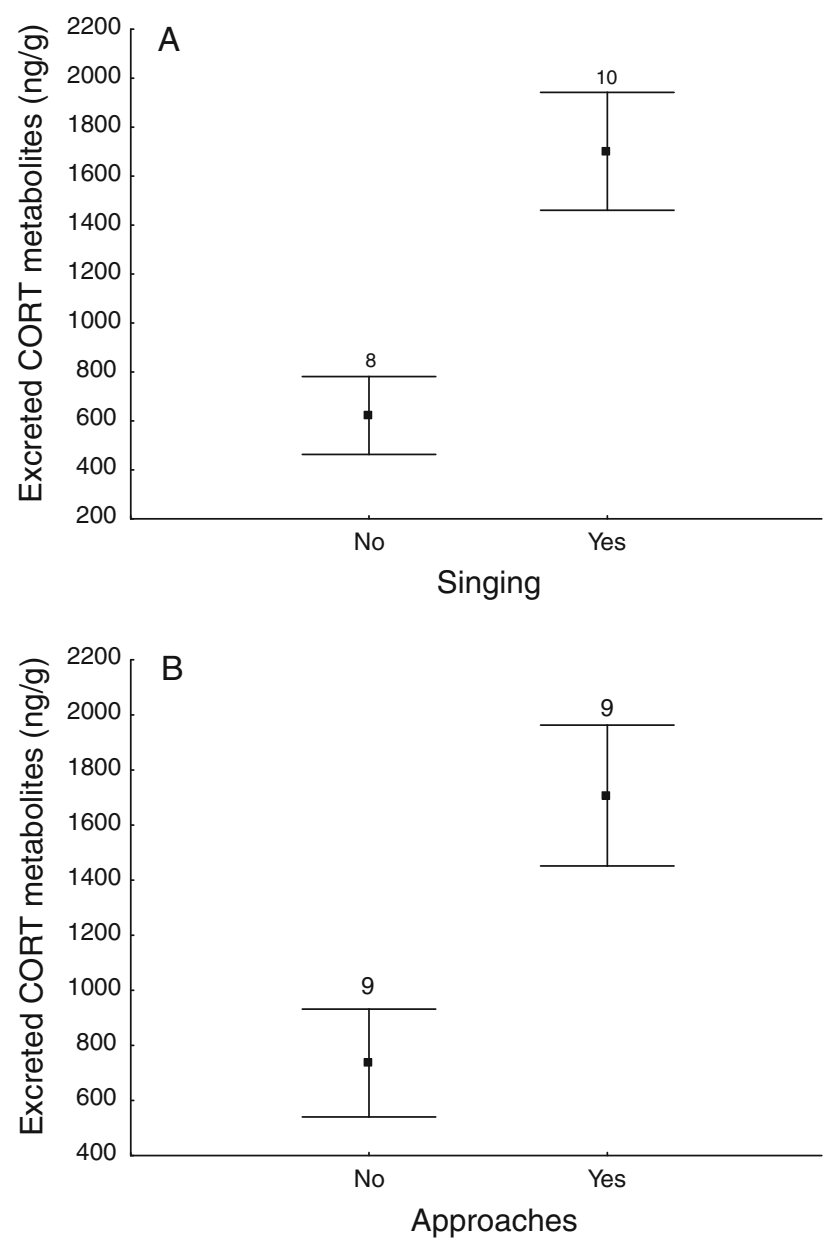

Fig. 2 Mean \pm SE CORT metabolites concentration of males that expressed singing behavior (a) or approximation (b) behavior when exposed to a playback of a conspecific male under their nestbox

need for $\mathrm{O}_{2}$ to supply energy production in high demanding situations requiring CORT secretion. In wild, incubating Common Eiders (Somateria mollisima), HSP levels (HSP60 and HSP70) and CORT levels tended to vary in opposite directions with incubation stage, although a nonsignificant association was found between CORT and HSPs (HSP70 and HSP60; Bourgeon et al. 2006), which could suggest that the potential association of these physiological parameters may be dependent on the specific stage of the reproductive cycle and the ecological context.

Given the role of glucocorticoids in the increase of energy mobilization, high hormone secretion may drive a decrease in body mass. In fact, a negative relationship between CORT levels and body condition has been observed in many studies, frequently in association with adverse conditions (i.e., Cherel et al. 1988; Marra and Holberton 1998; Kitaysky et al. 1999; Breuner and Hahn 2003), while other studies have not found an association between CORT levels and body condition (Lormée et al. 2003; Poisbleau et al. 2005). In general, a negative association with body condition is expected at stress-related levels of glucocorticoids and not at seasonal glucocorticoid levels (reviewed at Landys et al. 2006). Our data show no relationship between CORT metabolites and body condition, suggesting that CORT metabolites are measured at a baseline level in our study. Moreover, male Pied Flycatchers were sampled at the last stage of migration, and it has been reported in other species of migrating birds that CORT levels circulate at elevated baseline levels during migration and not at stressed-related levels (LandysCiannelli et al. 2002).

As glucocorticoids promote the mobilization of energy stores, their secretion may facilitate the expression of energetically expensive reproductive functions. Migration and territorial competition in males are energetically demanding activities influenced by sexual selection that may be associated with the secretion of glucocorticoid hormones. Our study shows that an early arrival from migration in the Pied Flycatcher may require a high mobilization of energy in this tropical migrant, as indicated by the elevated baseline levels of CORT metabolites observed in early individuals. Arriving early on the breeding area provides benefits in terms of sexual selection, as early individuals show higher probabilities of acquiring the best mates (Potti and Montalvo 1991a). However, an early arrival may not be exempt from costs as it may be associated with hard weather conditions on migration or the onset of reproduction (Kokko 1999; Brown and Brown 2000). Thus, the variation in the exposure to harsh conditions during migration could translate into individual variation in physiological variables directed at surmounting high energy demanding situations. In fact, our study shows that early arriving individuals have higher baseline CORT metabolite levels, which could indicate that an early arrival may be associated with an increased allostatic load. We may speculate that, if the advance of arrival was notable, it could be that the allostatic load of early individuals increased and the CORT responses escalated until stressrelated levels were reached. In this case, the stress-related hormone levels could lead to immunosuppressive and other negative effects on the organism (Sapolsky et al. 2000; Sapolsky 2000) that would impose physiological costs on too-early individuals (Kokko 1999; Moreno et al. 2001).

Dominant high-quality individuals may require lower CORT levels than subdominants for the same level of migratory exertion (Creel 2001). The white forehead patch in Ficedula males has been associated with increased mating advantage (Potti and Montalvo 1991a; Qvarnström et al. 2000; but see Dale et al. 1999). The size of this patch is a condition-dependent character that responds to past reproductive effort in the related Collared Flycatcher (Ficedula albicollis) (Gustafsson et al. 1995). Also, male behavior has been reported to be affected by the forehead 
patch size, as individuals with experimentally enlarged patches have been shown to display a more intense territorial behavior (Osorno et al. 2006). The negative association of baseline CORT metabolite levels and forehead patch size could arise due to the role of forehead patches in male contest. It has been reported that male Collared Flycatchers with larger patches are more successful in gaining territories (Pärt and Qvarnström 1997). Black male plumage has also been related to mating advantage (Järvi et al. 1987; Saetre et al. 1994; but see Alatalo et al. 1990). However, CORT metabolites were not associated with this ornamental trait. On the contrary, our data show that forehead patch size is inversely related to CORT metabolites, which suggests that dominance as expressed by bigger forehead patches is associated to low baseline CORT metabolites.

Territorial defense comprises a variety of aggressive and advertisement behaviors that may be energetically demanding. One of the aspects associated with territorial defense is singing, and different song characteristics have been shown to be limited by ecological and physiological constraints (i.e., Saino et al. 1996; Gil and Gahr 2002; Garamszegi et al. 2006). Elevated levels of CORT have been observed in territorial males of different species, probably as a reflection of the high energetic requirements of intense aggressive behaviors (Moore and Jessop 2003; Goymann and Wingfield 2004; Berger et al. 2005). It has also been reported that territorial challenges may affect CORT levels (Sorenson et al. 1997; Van Duyse et al. 2004; Landys et al. 2007). Our data indicate that approaching a playback recorder and singing as a response to a playback of an intruder were positively associated with high CORT metabolite levels of Pied Flycatchers. The association between CORT metabolites and behavior may have also arisen through mechanisms not necessarily associated with the role of CORT in facilitating energy mobilization to support territorial behavior. It could be that the association of the history of CORT secretion as measured through CORT metabolites with territorial behavior registered 5 days later may have arisen due to a direct role of CORT on the promotion of aggressive behavior. In fact, studies in mammals have shown that glucocorticoids may have a direct regulatory role on the promotion of aggressive behaviors (Hayden-Hixson and Ferris 1991; Haller et al. 1997; Mikics et al. 2004, 2007).

Overall, our study suggests that early arrival in males is associated with elevated CORT metabolite levels and implies a high allostatic load. Also, dominance in males as expressed by a larger white forehead patch is associated with lower CORT metabolite levels. Our data suggest that high levels of CORT metabolites may facilitate an intense territorial competition in males. Recently, Husak and Moore (2008) have reviewed the evidence showing that glucocorticoids may be under the direct or indirect influence of sexual selection. We show here that sexual selection for early arrival and territory acquisition are associated with baseline CORT metabolite levels in males. Thus, male-male competition may be a factor affecting observed baseline glucocorticoid levels in migratory birds.

\section{Zusammenfassung}

Beim männlichen Trauerschnäpper (Ficedula hypoleuca) stehen Ankunftsdatum und

Territorealverhalten mit den

Corticosteroidmetabolitenwerten in Zusammenhang

Glucocorticoide fördern die Mobilisation von Energiereserven und könnten die Expression energetisch kostspieliger Funktionen erleichtern. Bei Zugvögeln sind eine frühe Ankunft im Brutgebiet und die Konkurrenz um Territorien energetisch anspruchsvolle Aktivitäten, die durch erhöhte Baseline-Glucocorticoidwerte gefördert werden könnten. Hier haben wir die Zusammenhänge zwischen der Ankunftszeit männlicher Trauerschnäpper (Ficedula hypoleuca) und den Baseline-Werten ausgeschiedener Corticosteron(CORT)metabolite direkt nach der Ankunft im Brutgebiet ausgewertet, unter Berücksichtigung von Ornamenten, die den sozialen Status anzeigen (z.B. Größe des Stirnflecks, schwarze Gefiederfärbung), sowie Hitzeschockproteinwerten (HSP60). Wir haben einen positiven Zusammenhang zwischen CORT-Metaboliten und den Werten von HSP60-Proteine, die unter schwierigen, die Zellhomöostase beeinträchtigenden Umweltbedingungen synthetisiert werden, festgestellt. Unsere Daten zeigten einen negativen Zusammenhang zwischen dem Ankunftsdatum und den CORT-Metabolitwerten auf, möglicherweise als Ergebnis eines höheren Energiebedarfs infolge der harten Umweltbedingungen, welche die Zugvögel bei einer frühen Ankunft erfahren. Wir haben einen negativen Zusammenhang zwischen der Größe des Stirnflecks und den CORT-Metabolitwerten beobachtet, was darauf hindeutet, dass soziale Dominanz mit niedrigen Baseline-CORT-Metaboliten zusammenhängt. Außerdem hatten Männchen, die stärkeres Territorialverhalten zeigten, wenn sie dem Playback-Gesang eines Artgenossen an ihrem Nistkasten ausgesetzt waren, höhere CORT-Metabolite bei ihrer Ankunft als Männchen, die weniger ausgeprägtes Territorialverhalten zeigten. Dies könnte darauf hindeuten, dass erhöhte Baseline-CORT-Metabolitwerte bei Männchen starke Territorialkonkurrenz fördern könnten. Wir vermuten, dass die Konkurrenz zwischen Männchen ein Faktor ist, der die bei Zugvögeln gemessenen Baseline-Glucocorticoidwerte beeinflusst. 
Acknowledgments This paper is dedicated to the memory of José Luis Osorno who planned this study during a sabbatical leave in Madrid in 2002-2003. The study has received financial support from projects CGL2004-00787/BOS and CGL2007-61251 to J. Moreno and BOS2003-05724 and CGL2006-14129-C02-01/BOS to S.M. (DGI-Ministerio de Ciencia e Innovación). All procedures conform to the requirements of animal welfare and conservation of Spanish laws. J. Morales and G.T. were supported by grants from MEC and Comunidad de Madrid respectively. E.L. was supported by a FPU grant from MEC. R.A.V. acknowledges support from a grant CSIC-Universidad de Chile 2003-04-09, ICM,-P05-002, and PFB-23-CONICYT-Chile. Consuelo Corral and Tonantzin Calvo helped in the field. We thank Chris Guglielmo and an anonymous reviewer for their constructive comments on a previous version of this manuscript. We were authorized by Javier Donés, Director of the Montes de Valsaín reserve, to work in the study area. Dirección General del Medio Natural-Junta de Castilla y León authorized the capture, ringing, and blood sampling of birds. This paper is a contribution from the El Ventorrillo field station.

\section{References}

Alatalo R, Lundberg A, Sundberg J (1990) Can female preference explain sexual dichromatism in the pied flycatcher Ficedula hypoleuca? Anim Behav 39:244-252

Andersson M (1994) Sexual selection. Princeton University Press, Princeton

Barr CS, Dokas LA (1999) Glucocorticoids regulate the synthesis of HSP27 in rat brain slices. Brain Res 13:9-17

Becker JB, Breedlove SM (2002) Introduction to behavioral endocrinology. In: Becker JB, Breedlove SM, Crews D, McCarthy MM (eds) Behavioral endocrinology, 2nd edn. MIT Press, Cambridge

Belthoff JR, Dufty AM Jr (1994) Plumage variation, plasma steroids and social dominance in male house finches. Condor 96:614-625

Berger S, Martin LB II, Wikelski M, Romero M, Kalko EKV, Vitousek MN, Rödl T (2005) Corticosterone suppresses immune activity in territorial Galápagos marine iguanas during reproduction. Horm Behav 47:419-429

Bourgeon S, Martínez J, Criscuolo F, Le Maho Y, Raclot T (2006) Fasting-induced changes of immunological and stress indicators in breeding female eiders. Gen Comp Endocrinol 147:336-342

Breuner CW, Hahn TP (2003) Integrating stress physiology, environmental change, and behavior in free-living sparrows. Horm Behav 43:115-123

Brown CR, Brown MB (2000) Weather-mediated natural selection on arrival time in cliff swallows (Petrochelidon pyrrhonota). Behav Ecol Sociobiol 47:339-345

Cherel Y, Robin JP, Walch O, Karmann H, Netchitailo P, Le Maho Y (1988) Fasting in king penguin. I. Hormonal and metabolic changes during breeding. Am J Physiol Regul Integr Comp Physiol 254:170-177

Creel S (2001) Social dominance and stress hormones. Trends Ecol Evol 16:491-497

Dale S, Slagsvold T, Lampe HM, Saetre GP (1999) Population divergence in sexual ornaments: the white forehead patch of Norwegian pied flycatchers is small and unsexy. Evolution 53:1235-1246

Darwin C (1871) The descent of man, and selection in relation to sex. Murray, London

Davies NB (1980) The economics of territorial behaviour in birds. Ardea 68:63-74

Ding Q, Vaynman S, Souda P, Whitelegge JP, Gomez-Pinilla F (2006) Exercise affects energy metabolism and neural plasticity- related proteins in the hippocampus as revealed by proteomic analyses. Eur J Neurosci 24:1265-1276

Drost R (1936) Über das Brutkleid männlicher Trauerfliegenschnäpper Muscicapa hypoleuca. Vogelzug 6:179-186

Feder ME, Hofmann GE (1999) Heat-shock proteins, molecular chaperones, and the stress response: evolutionary and ecological physiology. Annu Rev Physiol 61:243-282

Feige U, Polla BS (1994) HSP70 - a multigene, multistructure, multifunction with potential clinical applications. Experientia 50:979-986

Fisher RA (1930) The genetical theory of natural selection. Clarendon, Oxford

Fleshner M, Campisi J, Amiri J, Diamond DM (2004) Cat exposure induces both intra- and extracellular Hsp72: the role of adrenal hormones. Psychoneuroendocrinol 29:1142-1152

Folstad I, Karter AJ (1992) Parasites, brigth males and the immunocompetence handicap. Am Nat 139:603-622

Garamszegi LZ, Merino S, Török J, Eens M, Martínez J (2006) Indicators of physiological stress and the elaboration of sexual traits in the collared flycatcher. Behav Ecol 17:399-404

Gil D, Gahr M (2002) The honesty of bird song: multiple constraints for multiple traits. Trends Ecol Evol 17:133-141

Gottlander K (1987) Variation in the song rate of the male pied flycatcher Ficedula hypoleuca: causes and consequences. Anim Behav 35:1037-1043

Goymann W (2005) Noninvasive monitoring of hormones in bird droppings: physiological validation, sampling, extraction, sex differences and the influence of diet on hormone metabolite levels. Ann N Y Acad Sci 1046:35-53

Goymann W, Wingfield JC (2004) Allostatic load, social status and stress hormones: the cost of social status matter. Anim Behav 67:591-602

Gustafsson L, Qvarnström A, Sheldon BC (1995) Trade-offs between life-history traits and a secondary sexual character in male collared flycatchers. Nature 375:311-313

Haller J, Albert I, Makara GB (1997) Acute effects of corticosterone lack specificity but showed marked context dependency. J Neuroendocrinol 9:515-518

Hayden-Hixson DM, Ferris CF (1991) Cortisol exerts site-, contextand dose-dependent effects on agonistic responding in hamsters. J Neuroendocrinol 3:613-622

Herring G, Gawlik DE (2007) The role of stress proteins in the study of allostatic overload in birds: use and applicability to current studies in avian ecology. ScientificWorld J 28:15961602

Holberton RL (1999) Changes in patterns of corticosterone secretion concurrent with migratory fattening in a Neotropical migratory bird. Gen Comp Endocrinol 116:49-58

Holberton RL, Able KP, Wingfield JC (1989) Status signaling in dark-eyed juncos, Junco hyemalis: plumage manipulations and hormonal correlates of dominance. Anim Behav 37:681-689

Holberton RL, Parrish JD, Wingfield JC (1996) Modulation of the adrenocortical stress response in neotropical migrans during autumn migration. Auk 113:558-564

Husak JF, Moore IT (2008) Stress hormones and mate choice. Trends Ecol Evol 23:532-534

Järvi T, Røskaft E, Bakken M, Zumsteg B (1987) Evolution of variation in male secondary sexual characteristics. A test of eight hypotheses applied to pied flycatchers. Behav Ecol Sociobiol 20:161-169

Kilpimaa J, Alatalo RV, Siitari H (2004) Trade-offs between sexual advertisement and immune function in the pied flycatcher (Ficedula hypoleuca). Proc R Soc Lond B 271:245-250

Kitaysky AS, Wingfield JC, Piatt JF (1999) Dynamics of food availability, body condition and physiological stress response in breeding black-legged kittiwakes. Funct Ecol 13:577-584 
Kokko H (1999) Competition for early arrival in migratory birds. J Anim Ecol 68:940-950

Krebs JR (1980) Optimal foraging, predation risk and territory defence. Ardea 68:83-90

Kroodsma DE, Byers BE, Goodale E, Johnson S, Liu W (2001) Pseudoreplication in playback experiments, revisited a decade later. Anim Behav 61:1029-1033

Landys MM, Wingfield JC, Ramenosfky M (2004) Plasma corticosterone increases during migratory restlessness in the captive white-crowned sparrow Zonotrichia leucophrys gambelli. Horm Behav 46:574-581

Landys MM, Ramenofsky M, Wingfield JC (2006) Actions of glucocorticoids at a seasonal baseline as compared to stressrelated levels in the regulation of periodic life processes. Gen Comp Endocrinol 148:132-149

Landys MM, Goymann W, Raess M, Slagsvold T (2007) Hormonal responses to male-male social challenge in the blue tit Cyanistes caeruleus: single-broodedness as an explanatory variable. Physiol Biochem Zool 80:228-240

Landys-Ciannelli MM, Ramenosfky M, Piersma T, Group CastricumRinging, Wingfield JC (2002) Baseline and stress-induced plasma corticosterone during long-distance migration in the bartailed godwit, Limosa lapponica. Physiol Biochem Zool 75:101110

Lobato E, Merino S, Moreno J, Morales J, Tomás G, Martínez-de la Puente J, Osorno JL, Kuchar A, Möstl E (2008) Corticosterone metabolites in blue tits and pied flycatcher droppings: effects of brood size, ectoraparasites and temperature. Horm Behav 53:295-305

Lormée H, Jouventin P, Trouve C, Chastel O (2003) Sex-specific patterns in baseline corticosterone and body condition changes in breeding red-footed boobies Sula sula. Ibis 145:212-219

Lundberg A, Alatalo RV (1992) The pied flycatcher. Academic, London

Marra PP, Holberton RL (1998) Corticosterone levels as indicators of habitat quality: effects of habitat segregation in a migratory bird during the non-breeding season. Oecologia 116:284-292

Martínez J, Pérez-Serrano J, Bernadina WE, Rodriguez-Caabeiro F (2001) Stress response to cold in Trichinella species. Cryobiology 43:293-302

McEwen BS, Wingfield JC (2003) The concept of allostasis in biology and biomedicine. Horm Behav 43:2-15

Merino S, Martínez J, Barbosa A, Møller AP, De Lope F, Pérez J, Rodríguez-Caabeiro F (1998) Increase in a heat shock protein from blood cells in response to parasitism of nestling house martins (Delichon urbica): an experimental approach. Oecologia 116:343-347

Merino S, Martínez J, Møller AP, Barbosa A, de Lope F, RodríguezCaabeiro F (2002) Blood stress protein levels in relation to sex and parasitism of barn swallows (Hirundo rustica). Ecoscience 9:300-305

Mikics E, Kruk MR, Haller J (2004) Genomic and non-genomic effects of glucocorticoids on aggressive behavior in male rats. Psychoneuroendocrinology 29:618-635

Mikics E, Barsi B, Haller J (2007) The effect glucocorticoids on aggressiveness in established colonies of rats. Psychoneuroendocrinology 32:160-170

Millspaugh JJ, Washburn BE (2004) Use of fecal glucocorticoid metabolite measures in conservation biology research: considerations for application and interpretation. Gen Comp Endocrinol 138:189-199

Møller AP (1994) Phenotype-dependent arrival time and its cosequences in migratory birds. Behav Ecol Sociobiol 35:115-122

Moore MC, Jessop TS (2003) Stress, reproduction and adrenocortical modulation in amphibians and reptiles. Horm Behav 43:39-47
Moreno J, Potti J, Yorio P, García-Borboroglu P (2001) Sex differences in cell-mediated immunity in the magellanic penguin Spheniscus magellanicus. Ann Zool Fenn 38:111-116

Moreno J, Merino S, Martínez J, Sanz JJ, Arriero E (2002) Heterophil/lymphocyte ratios and the heat-shock protein levels are related to growth in nestling birds. Ecoscience 9:434-439

Morimoto RI (1998) Regulation of the heat shock transcriptional response: cross talk between a family of heat shock factors, molecular chaperones, and negative regulators. Genes Dev 12:3788-3796

Möstl E, Maggs JL, Schrötter G, Besenfelder U, Palme R (2002) Measurement of cortisol metabolites in faeces of ruminants. Vet Res Commun 26:127-139

Newton I (2007) Weather-related mass-mortality events in migrants. Ibis 149:453-467

Olanrewaju HA, Wongpichet S, Thaxton JP, Dozier WA III, Branton SL (2006) Stress and acid-base balance in chickens. Poult Sci 85:1266-1274

Osorno JL, Morales J, Moreno J, Merino S, Tomás G, Vásquez RA (2006) Evidence for differential maternal allocation to eggs in relation to manipulated male attractiveness in the pied flycatcher (Ficedula hypoleuca). J Ornithol 147:605-611

Palme R, Rettenbacher S, Touma C, El-Bahr SM, Möstl E (2005) Stress hormones in mammals and birds. Comparative aspects regarding metabolism excretion and noninvasive measurement in fecal samples. Ann N Y Acad Sci 1049:162-171

Pärt T, Qvarnström A (1997) Badge size in collared flycatchers predict outcome of male competition over territories. Anim Behav 54:893-899

Piersma T, Reneerkens J, Ramenosfky M (2000) Baseline corticosterone peaks in shorebirds with maximal energy stores for migration: a general preparatory mechanism for rapid behavioral and metabolic transitions? Gen Comp Endocrinol 120:118-126

Poisbleau M, Fritz H, Guillon N, Chastel O (2005) Linear social dominance hierarchy and corticosterone responses in male mallard and pintails. Horm Behav 47:485-492

Potti J, Montalvo S (1991a) a male arrival and female mate choice in pied flycatchers Ficedula hypoleuca in Central Spain. Ornis Scand 22:45-55

Potti J, Montalvo S (1991b) Male colour variation in Spanish pied flycatchers Ficedula hypoleuca. Ibis 133:293-299

Pravosudov VV, Mendoza SP, Clayton NS (2003) The relationship between dominance, corticosterone, memory, and food caching in mountain chickadees (Poecile gambeli). Horm Behav 44:93-102

Qvarnström A, Pärt T, Sheldon B (2000) Adaptive plasticity in mate preference linked to differences in reproductive effort. Nature 405:344-347

Råberg L, Grahn M, Hasselquist D, Svensson E (1998) On the adaptive significance of stress-induced immunosupression. Proc R Soc Lond B 265:1637-1641

Rettenbacher S, Möstl E, Hackl R, Ghareeb K, Palme R (2004) Measurement of corticosterone metabolites in chicken droppings. Br Poult Sci 45:704-711

Romero LM, Romero RC (2002) Corticosterone responses in wild birds: the importance of rapid initial sampling. Condor 104:129_ 135

Romero LM, Ramenofsky M, Wingfield JC (1997) Season and migration alters the corticosterone response to capture and handling in an artic migrant, the white-crowned sparrow (Zonotrichia leucophrys gambelli). Comp Biochem Physiol C 116:171-177

Saetre GP, Dale S, Slagvold T (1994) Female pied flycatchers prefer brightly coloured males. Anim Behav 48:1407-1416

Saino N, Møller AP (1995) Sexual ornamentation and immunocompetence in the barn swallow. Behav Ecol 7:227-232 
Saino N, Galeotti P, Sacchi R, Møller AP (1996) Song and immunological condition in male barn swallows (Hirundo rustica). Behav Ecol 8:364-371

Sanz JJ, Potti J, Moreno J, Merino S, Frías O (2003) Climate change and fitness components of a migratory bird breeding in the Mediterranean region. Glob Change Biol 9:461-472

Sapolsky RM (2000) Stress hormones: good and bad. Neurobiol Dis 7:540-542

Sapolsky RM, Romero LM, Munck AU (2000) How do glucocorticoids influence stress responses? Integrating permissive, suppressive, stimulatory, and preparative actions. Endocr Rev 21:55-89

Schäfler AE, Kirmanoglou K, Pecher P, Hannekum A, Schumacher B (2002) Overexpression of heat shock protein 60/10 in myocardium of patiens with chronic atrial fibrillation. Ann Thorac Surg 74:767-770

Schlesinger MJ (1990) Heat shock proteins. J Biol Chem 265:1211112114

Schwabl H, Ramenosfsky M, Schwabl-Benzinger I, Farner DS, Wingfield JC (1988) Social status, circulating levels of hormones, and competition for food in winter flocks of the whitethroated sparrow. Behaviour 107:107-121

Smith RJ, Moore FR (2005) Arrival timing and seasonal reproductive performance in longdistace migratory landbird. Behav Ecol Sociobiol 57:231-239

Sørensen JG, Kristensen TN, Loeschke V (2003) The evolutionary and ecological role of heat shock proteins. Ecol Lett 6:1025-1037
Sorenson LG, Nolan PM, Brown AM, Derrickson SR, Monfort SL (1997) Hormonal dynamics during mate choice in the northern pintail: a test of the challenge hypothesis. Anim Behav 54:11171133

Svensson L (1984) Identification guide to European passerines. Ugga, Stockholm

Thambirajah AA, Sleigh K, Stiver HG, Chow AW (2008) Differential heat shock protein responses to strenuous standardized exercise in chronic fatigue syndrome patients and matched healthy controls. Clin Invest Med 31:319-327

Tomás G, Martínez J, Merino S (2004) Collection and analysis of blood samples to detect stress proteins in wild birds. J Field Ornithol 75:281-287

Tomás G, Merino S, Martínez J, Moreno J, Sanz JJ (2005) Stress protein levels and blood parasite infection in blue tits (Parus caeruleus): a medication field experiment. Ann Zool Fenn 42:45-56

Van Duyse E, Pinxten R, Darras VM, Arckens L, Eens M (2004) Opposite changes in plasma testosterone and corticosterone levels following a simulated territorial challenge in male great tits. Behaviour 141:451-567

Washburn BS, Moreland JJ, Slaughter AM, Werner I, Hinton DE, Sanders BM (2002) Effects of handling on heat shock protein expression in rainbow trout (Oncorhynchus mykiss). Environ Toxicol Chem 21:557-560 